\title{
Determinants of Virologic Failure Among Adults on Second Line Antiretroviral Therapy in Wollo, Amhara Regional State, Northeast Ethiopia
}

This article was published in the following Dove Press journal: HIVIAIDS - Research and Palliative Care

\author{
Ali Seid ${ }^{\prime}$ \\ Niguss Cherie ${ }^{2}$ \\ Kemal Ahmed (D) ${ }^{3}$ \\ 'Reproductive and Family Health Unit, \\ Dessie Health Science College, Dessie, \\ Ethiopia; ${ }^{2}$ Reproductive and Family \\ Health Unit, School of Public Health, \\ College of Medicine and Health Sciences, \\ Wollo University, Dessie, Ethiopia; \\ ${ }^{3}$ School of Public Health, College of \\ Medicine and Health Sciences, Wollo \\ University, Dessie, Ethiopia
}

Background: Treatment failure among the population on second line antiretroviral therapy is a major public health threat. In Ethiopia there has been limited research done on second line treatment failure.

Objective: To identify determinants of virologic failure among adults on second line antiretroviral therapy in six public hospitals of Wollo, Amhara regional state, northeast Ethiopia.

Methods: An institution-based unmatched case-control study was conducted from February 1, 2020 to April 30, 2020 on a total of 377 clients in six public hospitals of Wollo, Amhara regional state, northeast Ethiopia. Clients whose viral load result $>1,000$ copies $/ \mathrm{mL}$ in two consecutive results at least 3 month apart were cases, while $\leq 1,000$ copies/ $\mathrm{mL}$ were controls. The sample size was calculated by using Epi-Info version 7. Cases (94) and controls (283) were selected using a simple random sampling method in a ratio of casesto-controls of 1:3. The model fitted and binary logistic assumptions were fulfilled with $95 \%$ confidence level and $P$-values $<0.05$ were taken as statistically significant.

Results: Virologic failure was predicted by poor adherence $(\mathrm{AOR}=6.060,95 \% \mathrm{CI}=2.837-$ 12.944), not disclosing their HIV status ( $\mathrm{AOR}=4.178,95 \% \mathrm{CI}=1.431-12.198)$, OI $(\mathrm{AOR}=4.11,95 \% \quad \mathrm{CI}=1.827-9.246), \quad \mathrm{CD} 4$ count $<100 \quad$ cells $/ \mathrm{mm}^{3} \quad(\mathrm{AOR}=3.497,95 \%$ $\mathrm{CI}=1.233-9.923)$ and $100-350$ cells $/ \mathrm{mm}^{3}(\mathrm{AOR}=5.442,95 \% \mathrm{CI}=2.191-13.513)$, low BMI $<16 \mathrm{~kg} / \mathrm{m}^{2}(\mathrm{AOR}=7.223,95 \% \mathrm{CI}=2.218-23.520)$, and young age 15-29 years $(\mathrm{AOR}=2.898$, 95\% CI=1.171-7.170).

Conclusion and Recommendations: Determinants of second line ART virologic failure were patients who had poor adherence to ART, not disclosed, opportunistic infection, low CD4 counts $<350$ cell $/ \mathrm{mm}^{3}$, low BMI $\left(<16 \mathrm{~kg} / \mathrm{m}^{2}\right)$, and young age 15-29 year patients. Social support, disclosing their HIV status, and getting early treatment for any opportunistic infection is crucial to patients.

Keywords: HIV, second line ART, virologic failure, case-control study, Wollo, northeast Ethiopia

\section{Introduction}

Second line antiretroviral therapy (ART) virologic failure is defined as patients who are on second-line regimen and have a high viral load level $(>1,000$ copies $/ \mathrm{mL})$ in two consecutive measurement after 6 months of treatment and repeat test after 3 months to decide second line treatment virologic failure. ${ }^{1}$ It is well established that virological failure (the gold standard criteria) occurs earliest, followed by immunological failure, then clinical failure. ${ }^{2}$
Reproductive and Family Health Unit, School of Public Health, College of Medicine and Health Sciences, Wollo University, PO Box: I I45, Dessie, Ethiopia

Tel +25I 910749743

Email nigucheru@gmail.com 
First line virologic failure is a viral load count of more than 1,000 copies $/ \mathrm{mL}$ in two consecutive results at least 3 months apart after 6 months of switching to second line antiretroviral therapy. ${ }^{1,3}$ Patients using the WHO recommended second-line of boosted atazanavir have comparable virologic suppression to those on boosted lopinavir. ${ }^{4}$ Viral load monitoring has been recommended by the WHO for the identification of treatment failure and to prompt enhanced adherence support. ${ }^{5}$

Globally more than 36.9 million people were living with HIV by the end of 2017. ${ }^{5}$ Sub-Saharan Africa carries the highest burden with an estimated 24.7 million people living with $\mathrm{HIV}$, nearly $70 \%$ of the global total. ${ }^{6}$ According to the 2014 UNAIDS report, around 1.7 million people died from AIDS related causes worldwide and $70 \%$ occurred in sub-Saharan Africa. ${ }^{7}$ Ethiopia is one of the hardest hit sub-Saharan African countries by the HIV pandemic with an estimated death of 52,405 by $2014 .^{8}$

According to the global estimate, about $5.5 \%$ of patients were receiving second-line treatment in 2016 worldwide. In sub-Saharan Africa, nearly two out of 100 HIV patients switched to second line ART every year. Patients on second-line treatment accounted for $1.5 \%$ of all patients on ART in Ethiopia. ${ }^{9}$ In Amhara regional state the overall incidence of second-line treatment failure was 9.86 per 100 person-years. ${ }^{10}$

Studies from Asia reported that after 2 years on second-line ART, failure rates ranged between $8 \%$ and $41 \%$, and studies from Africa reported that the rate was between $13 \%$ and $40 \% .{ }^{11}$ A higher rate of virological failure of $17.7 \%$ was reported in India among patients who were on second line ART beyond 1 year and a much higher rate of virological failure of $37 \%$ was also recently reported from Myanmar Asia among patients who were on second line ART. ${ }^{12}$ In a resource limited setting the rates of second-line failure have been demonstrated to be as high as $38 \%$ by 36 months. ${ }^{13}$

The three 90 treatment target sets the goal by 2020 : $90 \%$ of people living with HIV knowing their HIV status, $90 \%$ of people who know their HIV-positive status accessing treatment, and $90 \%$ of people on treatment having suppressed viral loads. ${ }^{14}$ Identifying factors contributing to viremia and virologic failure is key to achieving the third of the 90 targets. ${ }^{15}$

Treatment failure among the population on second line ART becomes a major public health threat. Its magnitude and factors leading to it are poorly defined. ${ }^{16}$ Patients who switch to second line ART factors leading to virologic failure are not well understood or well-studied. ${ }^{17}$ However, in Ethiopia there is much research conducted on first line antiretroviral treatment failure, but there is limited research conducted on second line treatment failure. This study tried to identify determinants of second line antiretroviral therapy virologic failure in six public hospitals of Wollo Amhara regional state, northeast Ethiopia.

This study finding is crucial to people living with HIV staying healthy, improving their life expectancy and quality-of-life, decreasing their HIV associated morbidity and mortality, and preventing drug toxicity and others. In addition, the clinicians and healthcare workers will benefit from this study to assist and focus on monitoring treatment for susceptible patients, achieving viral suppression, and preventing second line treatment failure by addressing the determinants identified. It is also crucial for local and health facility managers to develop operational planning and avail third line antiretroviral therapy in the health facilities.

\section{Methods and Materials Study Area, Period, and Design}

The study was conducted in six public hospitals of Wollo (Lalibela general, Woldia zonal, Dessie referral, Borumeda general, Mekaneselam primary and Hidar 11 general hospitals) of Amhara regional state, northeast Ethiopia. The total number of health workers was 1,691, 23 adherence counselors, and 17 case managers were working at ART clinics of the above hospitals. Generally in all study public hospitals 12,589 adults and 1,011 children were on first line ART, 1,301 adults were on second line ART, and 97 adults on second line ART were virologic results not suppressed. At the time of data collection there were 27 clients switched to third line ART at Dessie referral and Woldia zonal hospitals. Both hospitals started third line ART treatment at the end of February $2020 .{ }^{18}$ The study was conducted from February 1, 2020 to April 30, 2020. A facility-based unmatched case-control study design was conducted.

\section{Population}

All HIV positive adults $\geq 15$ years after 6 months switched to second line ART in a study of hospitals in Wollo, Amhara regional state, northeast Ethiopia. HIV positive adults $\geq 15$ years old, 6 months after switching to second line ART whose plasma viral load was $>1,000$ copies $/ \mathrm{mL}$ 
in two subsequent viral load measurements at least 3 months apart were cases (virologic failure), while study participants with a viral load level of $\leq 1,000$ copies $/ \mathrm{mL}$ were controls (virologic suppression).

\section{Eligibility Criteria}

HIV positive adults $\geq 15$ years old, 6 months after switching to second line ART who had $>1,000$ copies $/ \mathrm{mL}$ in two subsequent viral load results at least 3 months apart for the cases and who had suppressed viral load results were included. But those who were referred from other treatment centers with incomplete information (baseline C.D.4 count, baseline WHO stage, baseline BMI of patients in $\mathrm{kg} / \mathrm{m}^{2}$, and opportunistic infection) and transferred out to other health facilities were excluded.

\section{Sample Size and Sampling Technique}

The sample size was calculated by using Epi-Info version 7 by taken the key predictors of virologic failure from a previous study. The following assumptions were considered during sample size determination, from the study $95 \%$ confidence level, Odds ratio $=3.4$, power $=80 \%$, and a ratio of controls to cases of 3:1 was used. Therefore, the largest calculated sample size were 343 and, by adding a $10 \%$ non-response rate the total sample size was 377 clients (94 cases and 283 controls). All six public hospitals found in Wollo, Amhara regional state, northeast Ethiopia were included. The list of clients whose viral load results were available up to January 30, 2020 were extracted from a database computer in each ART clinic of study facilities. Then 94 cases whose viral load results were $>1,000$ copies/mL in two subsequent viral load measurements and 283 controls whose viral load results were suppressed were selected based on proportional allocation by using a computer generated simple random sampling method in the ratio of controls to cases of $3: 1$.

\section{Data Quality Control}

The data collection tool was an interview administered structured questionnaire for primary data and checklist for document review. It was adapted from other similar studies and the Federal Ministry of health Ethiopian ART national guidelines, register, intake and follow-up form of the patient. The questionnaire was originally developed in English and used as if for secondary data collection and translated to Amharic for primary data collection. Pretest was done in $5 \%$ of the patient at Dessie referral hospital before actual data collection. Data was collected by trained data collectors. Two days training was given to data collectors. Seven ART trained health professionals (five BSc and two clinical nurses) working at ART clinic in the study hospitals participated in the data collection. Supervision and on spot checking of the data collection procedure was made. Those who had no volunteer to participate in the study returned the questionnaires.

\section{Data Management and Analysis}

First data were checked for completeness. After being coded it was entered into EPI-data version 3.1, then it was checked for accuracy, consistency, and missing values through tabulation and frequency. Then it was transferred to Statistical Package for Social Science (SPSS) version 21 for analysis. The model fitness was checked by using Hosmer and Lemeshow goodness of test. Logistic regression assumption checked for filling of the assumption by using $\mathrm{VIF}<10$, tolerance test $>0.1$, and standard error $<2$. All fulfilled the assumptions. Then bivariable logistic regression was run and variables with a $P$-value of less than 0.25 were entered into a multivariable binary logistic regression model for further analysis. Data were interpreted by using odds ratios with $95 \%$ confidence level and a $P$-value $<0.05$ was taken as statistically significant.

\section{Operational Definitions}

\section{Second Line ART Virologic Failure}

Viral load result $>1,000$ copies/mL after 6 months were switched to second line ART in two subsequent measurements at least 3 months apart. ${ }^{1}$

\section{Cases}

All HIV positive adults $\geq 15$ years old whose plasma viral load result was $>1,000$ copies $/ \mathrm{mL}$ in two subsequent viral load measurements at least 3 months apart after 6 months of being switched to second line ART were cases (virologic failure). ${ }^{1}$

\section{Controls}

All HIV positive adults $\geq 15$ years old whose plasma viral load was $\leq 1,000$ copies $/ \mathrm{mL}$ after 6 months of switching to second line ART were controls (virologic suppression). ${ }^{1}$

\section{Adherence}

Assessed by patients self-report about missed doses within a month, missing more than three doses from BID doses and missing more than one dose from daily doses was considered as poor adherence. ${ }^{1}$ 


\section{Opportunistic Infections}

Infections that develop as a result of HIV-inflicted damage to the immune system (TB, PCP, gastrointestinal OI, herpes simplex, herpes zoster, fungal infection) and other national ART guidelines define opportunistic infection. ${ }^{1}$

\section{Lost to Follow-Up}

Patient's with three or more consecutive missed clinic appointments in medical record. ${ }^{1}$

\section{Defaulter}

Patient's with less than three consecutive missed clinic appointments. ${ }^{1}$

\section{Results}

\section{Socio-Demographic Characteristics}

From the total of 377 patients on second line ART in six public hospitals of Wollo, 363 (87 cases and 276 controls) participated in this study, which accounts for a response rate of $96.2 \%$. Among the participants, 201 (55.4\%) were females and $251(69.1 \%)$ respondents were urban residents. From the respondents, $136(37.5 \%)$ are $\geq 40$ years, 93 (25.6\%) 1529years, and 134 (36.9\%) were 30-39 years. Among respondents, 282 (77.7\%) had full or part time work (Table 1).

\section{Behavioral and Other Characteristics}

From the study participants, $46(52.9 \%)$ of the cases and $36(13 \%)$ of the controls had poor adherence to ART medication. Among the participants, 32 (36.8\%) cases and $16(5.8 \%)$ controls did not disclose their HIV status. From the respondents, 21 (5.8\%), 12 (3.3\%), and 68 $(18.7 \%)$ had a history of alcohol use, cigarette smoking, and chat chewing, respectively. Most of the clients (239, $65.8 \%$ ) were not correctly or consistently useing a condom, and $34(9.4 \%)$ had a history of default or missed less than three consecutive clinic appointments.

The majority of study participants $(300,82.6 \%)$ used a wall chart or mobile alarm ARV reminder to take their medication and the rest used family or friend, TV or radio. One hundred and eighty (49.6\%) of the clients travelled more than $10 \mathrm{~km}$ from their home to get the service. Of those, $322(88.7 \%)$ had a caretaker and 331 (91.2\%) of participants had no fear of stigma due to HIV/AIDS or use of ART medication. Finally, among the study participants, $311(85.6 \%)$ did not not manifest depression in the last 2 weeks during the data collection period.

\section{Clinical and Related Characteristics}

Since the study participants started ART medication, 309 (85.1\%) clients were more than 36 months on first line ART, $228(62.8 \%)$ were on second line ART for less than 2 years, and $343(94.5 \%)$ had a less than 12 months delay before switching to second line ART.

From the study participants $184(50.7 \%)$ were on TDF +3TC+ATV/r, 70 (19.3\%) on AZT+3TC+ATV/r, 69 (19\%) on $\mathrm{ABC}+3 \mathrm{TC}+\mathrm{ATV} / \mathrm{r}$, and the rest were on other ART regimens $(\mathrm{TDF}+3 \mathrm{TC}+\mathrm{LPV} / \mathrm{r}, \quad \mathrm{AZT}+3 \mathrm{TC}+\mathrm{LPV} / \mathrm{r})$ and, based on the doses, 193 (53.2\%) clients were taking one dose, whereas $170(46.8 \%)$ were taking two or more doses per day. From the total study participants, $315(86.8 \%)$ and $292(80.4 \%)$ used INH and CPT, respectively. Related to opportunistic and other infections, 321 (88.4\%) had no history of TB, 350 (96.4\%) had no chronic diarrhea, 337 (92.8\%) had no anemia, and 354 (97.5\%) had no adverse drug reaction. Finally, among the respondents, 296 $(81.5 \%)$ received three or more sessions of enhanced adherence counseling (Table 2).

\section{Determinants of Virologic Failure}

In bi-variable logistic regression from a total of 41 variables the following: sex, age, marital status, educational status, employment status, smoking, adherence, disclosure status of HIV, HIV status of spouse, condom use, history of default, ARV reminder use, type of health facility use ART, home-to-health facility distance, depression, functional status, opportunistic infection, body mass index, base line CD4 count, WHO T-stage, duration on first line ART, ART regimen, duration on second line ART, INH use, history of TB, anemia, diarrhea, and EAC session received passed the screening criteria $(P$-value $<0.25)$ for further multivariable binary regression (Table 3 ).

In multivariable binary logistic regression the likelihood of developing virologic failure among patients with poor adherence to ART medication was 6-times (AOR $=6.060,95 \% \mathrm{CI}=2.837-12.944)$ more likely as compared to those patients who had good adherence. Among study participants those patients who did not disclose their HIV status or use of ART medication were 4-times (AOR=4.178, 95\% $\mathrm{CI}=1.431-12.198)$ more likely to develop virologic failure as compared to those patients who disclosed their HIV status or use of ART medication to current parent or close relatives but in contrast to this those patients disclosed their HIV status or use of ART medication to friends or colleagues were $76.8 \%$ 
Table I Socio-Demographic Characteristics of Patients on Second Line Anti-Retroviral Therapy After 6 Months of Switched in Six Public Hospitals in Wollo, Amhara Regional State, Northeast Ethiopia in 2020

\begin{tabular}{|c|c|c|c|c|}
\hline \multicolumn{2}{|l|}{ Variable } & \multicolumn{2}{|l|}{ Virologic Failure } & \multirow{4}{*}{$\begin{array}{l}\text { Total (363) No. (\%) } \\
162(44.6) \\
20 \mid(55.4)\end{array}$} \\
\hline & & \multirow{3}{*}{$\begin{array}{l}\text { Cases (N=87) No. (\%) } \\
47(54) \\
40(46)\end{array}$} & \multirow{3}{*}{$\begin{array}{l}\text { Controls (N=276) No. (\%) } \\
115(41.7 \\
161(58.3)\end{array}$} & \\
\hline Sex & Male & & & \\
\hline & Female & & & \\
\hline \multirow[t]{3}{*}{ Age } & $\geq 40$ years & $23(26.4)$ & $113(40.9)$ & I36 (37.5) \\
\hline & 15-29 years & $40(46)$ & $53(19.2)$ & $93(25.6)$ \\
\hline & $30-39$ years & $24(27.6)$ & 110 (39.9) & $134(36.9)$ \\
\hline \multirow[t]{2}{*}{ Residence } & Urban & $64(73.6)$ & $187(67.8)$ & $25 I(69.1)$ \\
\hline & Rural & $23(26.4)$ & $69(32.2)$ & $112(30.9)$ \\
\hline \multirow[t]{4}{*}{ Marital status } & Single & $26(29.9)$ & $56(20.3)$ & $82(22.6)$ \\
\hline & Married & $28(32.2)$ & $|4|(5||)$. & $169(46.6)$ \\
\hline & Divorced & $24(27.6)$ & $53(19.2)$ & $77(2 \mid .2)$ \\
\hline & Widowed & $9(10.3)$ & $26(9.4)$ & $35(9.6)$ \\
\hline \multirow[t]{4}{*}{ Educational status } & Illiterate & $8(9.2)$ & $58(2 I)$ & $66(18.2)$ \\
\hline & Read and write & $8(9.2)$ & $46(16.7)$ & $54(14.9)$ \\
\hline & Elementary & $29(33.3)$ & $95(34.4)$ & $124(34.2)$ \\
\hline & Secondary and above & $42(48.3)$ & 77 (27.9) & $119(32.8)$ \\
\hline \multirow[t]{2}{*}{ Employment status } & Full or partial time work & $59(67.8)$ & $223(80.8)$ & $282(77.7)$ \\
\hline & Unemployed & $28(32.2)$ & $53(19.2)$ & $81(22.3)$ \\
\hline \multirow[t]{4}{*}{ Monthly income } & $>5,000$ birr & $3(3.4)$ & $10(3.6)$ & $13(3.6)$ \\
\hline & $\leq 1,000$ birr & $60(69)$ & 197 (7I.4) & $257(70.8)$ \\
\hline & $\mathrm{I}, 00 \mathrm{I}-2,500 \mathrm{birr}$ & $17(19.5)$ & 55 (19.9) & $72(19.8)$ \\
\hline & $2,50 \mathrm{I}-5,000 \mathrm{birr}$ & $7(8)$ & $14(5.1)$ & $21(5.8)$ \\
\hline
\end{tabular}

$(\mathrm{AOR}=0.232,95 \% \quad \mathrm{CI}=0.095-0.566)$ less likely to develop virologic failure as compared to those who disclosed their HIV status or use of ART medication to parents or close relatives.

Those patients who had opportunistic infection in their medical record were 4-times $(\mathrm{AOR}=4.11,95 \% \mathrm{CI}=1.827$ 9.246) more likely to develop virologic failure as compared to those who had no opportunistic infection. Among the respondents those patients who had a CD4 count $<100$ cells $/ \mathrm{mm}^{3}$ were 3.4-times $(\mathrm{AOR}=3.497,95 \% \mathrm{CI}=1.233$ 9.923) and those who had CD4 count of 100-350 cells/ $\mathrm{mm}^{3}$ were 5.4-times $(\mathrm{AOR}=5.442,95 \% \mathrm{CI}=2.191-13.513)$ more likely to develop virologic failure as compared to those who had a CD4 count $\geq 350$ cells $/ \mathrm{mm}^{3}$.

In addition, those patients who had low $\mathrm{BMI}<16 \mathrm{~kg} / \mathrm{m}^{2}$ were 7.2-times $\quad(\mathrm{AOR}=7.223, \quad 95 \% \quad \mathrm{CI}=2.218-23.520)$ more likely to develop virologic failure as compared to those with normal BMI $\left(\geq 18.5 \mathrm{~kg} / \mathrm{m}^{2}\right)$. Finally, patients whose age group was 15-29years were 2.8-times $(\mathrm{AOR}=2.898,95 \% \quad \mathrm{CI}=1.171-7.170)$ more likely to develop virologic failure as compared to those $\geq 40$ years age.

\section{Discussion}

The objective of this study was to identify determinants of virologic failure among adults' $\geq 15$ years old on second line anti-retroviral therapy in six public hospitals of Wollo, Amhara regional state, northeast Ethiopia by 2020. The study identified that poor adherence to ART medication, those who did not disclose their HIV status, those with a history of opportunistic infection, a CD4 count less than 350 cells $/ \mathrm{mm}^{3}$ when switched to second line ART treatment, low BMI $\left(<16 \mathrm{~kg} / \mathrm{m}^{2}\right)$, and a young age group 15-29 years were associated with second line ART virologic failure.

The study identified poor adherence to ART medication was more likely to develop virologic failure as compared with good adherence. This is line with a study conducted in south Africa and Northwestern Tanzania which shows poor adherence was a strong predictor of second-line ART failure. ${ }^{12,19}$ In Rwanda and Kenya, 
Table 2 Clinical and Related Characteristic of Patients on Second Line Anti-Retroviral Therapy After 6 Months of Switched in Six Public Hospitals of Wollo, Amhara Regional State, Northeast Ethiopia in 2020

\begin{tabular}{|c|c|c|c|c|}
\hline \multicolumn{2}{|l|}{ Variable } & \multicolumn{2}{|l|}{ Virologic Failure } & \multirow{3}{*}{$\begin{array}{l}\text { Total (363) No. (\%) } \\
355(97.8) \\
8(2.2)\end{array}$} \\
\hline & & Cases $(\mathrm{N}=87)$ No. (\%) & Controls $(\mathrm{N}=276)$ No. (\%) & \\
\hline Functional status & $\begin{array}{l}\text { Working } \\
\text { Ambulatory }\end{array}$ & $\begin{array}{l}81(93.1) \\
6(6.9)\end{array}$ & $\begin{array}{l}274(99.3) \\
2(0.7)\end{array}$ & \\
\hline ADR in medical history & $\begin{array}{l}\text { Yes } \\
\text { No }\end{array}$ & $\begin{array}{l}3(3.4) \\
84(96.6)\end{array}$ & $\begin{array}{l}6(2.2) \\
270(97.8)\end{array}$ & $\begin{array}{l}9(2.5) \\
354(97.5)\end{array}$ \\
\hline Opportunistic infection & $\begin{array}{l}\text { Yes } \\
\text { No }\end{array}$ & $\begin{array}{l}42(48.3) \\
45(51.7)\end{array}$ & $\begin{array}{l}33(12) \\
243(88)\end{array}$ & $\begin{array}{l}75(20.7) \\
288(79.3)\end{array}$ \\
\hline CD4 at switching 2nd line ART & $\begin{array}{l}\geq 350 \text { cells } / \mu \mathrm{ul} \\
100-350 \mathrm{cells} / \mu \mathrm{l} \\
<100 \mathrm{cells} / \mu \mathrm{l}\end{array}$ & $\begin{array}{l}34(39.1) \\
27(31) \\
26(29.8)\end{array}$ & $\begin{array}{l}223(80.8) \\
31(11.2) \\
22(7.9)\end{array}$ & $\begin{array}{l}257(70.8) \\
58(16) \\
48(13.2)\end{array}$ \\
\hline WHO stage & $\begin{array}{l}\text { Stage I } \\
\text { Stage II } \\
\text { Stage III } \\
\text { Stage IV }\end{array}$ & $\begin{array}{l}46(52.9) \\
14(16.1) \\
22(25.3) \\
5(5.7)\end{array}$ & $\begin{array}{l}240(87) \\
24(8.7) \\
8(2.9) \\
4(1.4)\end{array}$ & $\begin{array}{l}286(78.8) \\
38(10.5) \\
30(8.3) \\
9(2.5)\end{array}$ \\
\hline $\mathrm{BMl}$ in $\mathrm{kg} / \mathrm{m} 2$ & $\begin{array}{l}\geq 18.5 \mathrm{~kg} / \mathrm{m}^{2} \\
16-18.49 \mathrm{k} / \mathrm{m}^{2} \\
<16 \mathrm{~kg} / \mathrm{m}^{2}\end{array}$ & $\begin{array}{l}46(52.9) \\
17(19.5) \\
24(27.6)\end{array}$ & $\begin{array}{l}236(85.5) \\
28(10.1) \\
12(4.3)\end{array}$ & $\begin{array}{l}282(77.7) \\
45(12.4) \\
36(9.9)\end{array}$ \\
\hline Duration in first line ART in month & $\begin{array}{l}>36 \text { months } \\
\leq 36 \text { months }\end{array}$ & $\begin{array}{l}65(74.7) \\
22(25.3)\end{array}$ & $\begin{array}{l}244(88.4) \\
32(I I .6)\end{array}$ & $\begin{array}{l}309(85.1) \\
54(14.9)\end{array}$ \\
\hline Duration on second line ART in months & $\begin{array}{l}\geq 2 \text { years } \\
<2 \text { years }\end{array}$ & $\begin{array}{l}24(27.6) \\
63(72.4)\end{array}$ & $\begin{array}{l}\text { II I (40.2) } \\
\text { I } 65(59.8)\end{array}$ & $\begin{array}{l}135(37.2) \\
228(62.8)\end{array}$ \\
\hline 2 nd line regimen change & $\begin{array}{l}\text { Yes } \\
\text { No }\end{array}$ & $\begin{array}{l}5(5.7) \\
82(94.3)\end{array}$ & $\begin{array}{l}\text { I5 (5.4) } \\
26 \text { I (94.6) }\end{array}$ & $\begin{array}{l}20(5.5) \\
343(94.5)\end{array}$ \\
\hline INH used & $\begin{array}{l}\text { Yes } \\
\text { No }\end{array}$ & $\begin{array}{l}71(81.6) \\
16(18.4)\end{array}$ & $\begin{array}{l}244(88.4) \\
32(I I .6)\end{array}$ & $\begin{array}{l}315(86.8) \\
48(13.2)\end{array}$ \\
\hline History of TB treatment & $\begin{array}{l}\text { Yes } \\
\text { No }\end{array}$ & $\begin{array}{l}19(21.8) \\
68(78.2)\end{array}$ & $\begin{array}{l}23(8.3) \\
253(91.7)\end{array}$ & $\begin{array}{l}42(11.6) \\
321(88.4)\end{array}$ \\
\hline Lost follow-up in medical record & $\begin{array}{l}\text { Yes } \\
\text { No }\end{array}$ & $\begin{array}{l}4(4.6) \\
83(95.4)\end{array}$ & $\begin{array}{l}7(2.5) \\
269(97.5)\end{array}$ & $\begin{array}{l}\text { II (3) } \\
352(97)\end{array}$ \\
\hline CPT used & $\begin{array}{l}\text { Yes } \\
\text { No }\end{array}$ & $\begin{array}{l}72(82.8) \\
15(17.2)\end{array}$ & $\begin{array}{l}220(79.7) \\
56(20.3)\end{array}$ & $\begin{array}{l}292(80.4) \\
71(19.6)\end{array}$ \\
\hline Anemia in medical records & $\begin{array}{l}\text { Yes } \\
\text { No }\end{array}$ & $\begin{array}{l}14(16.1) \\
73(83.9)\end{array}$ & $\begin{array}{l}12(4.3) \\
264(95.7)\end{array}$ & $\begin{array}{l}26(7.2) \\
337(92.8)\end{array}$ \\
\hline
\end{tabular}

patients who were on second line ART with good adherence to ART were also significantly associated with viral suppression. $^{20,21}$ It is evident that individuals missing more than three doses from BID dose or more than one dose from daily dose of ART per month are associated with an increased risk of virological failure, leading to reduced immunity. This may result in them being exposed for opportunistic and other infections.
The study identified that those patients who did not disclose their HIV status were more likely to develop virologic failure as compared to those who disclosed to parents or close relatives, and those who disclosed their HIV status to friends or colleagues were less likely to develop virologic failure as compared to those who disclosed to parents or close relatives. In contrast to this study finding, a study conducted in South Africa shows those 
Table 3 Determinant Factors of Virology Failure Among Patients on Second Line Anti-Retroviral Therapy After 6 Months of Switched in Six Public Hospitals of Wollo, Amhara Regional State, Northeast Ethiopia in 2020

\begin{tabular}{|c|c|c|c|c|}
\hline \multirow[t]{2}{*}{ Independent Variable } & \multicolumn{2}{|c|}{ Virologic Failure } & \multirow[t]{2}{*}{ COR $(95 \% \mathrm{Cl})$} & \multirow[t]{2}{*}{ AOR $(95 \% \mathrm{Cl})$} \\
\hline & Yes & No & & \\
\hline \multicolumn{5}{|l|}{ Age } \\
\hline$\geq 40$ years & 23 & 113 & 1 & I \\
\hline $15-29$ years & 40 & 53 & $3.708(2.019-6.810)^{*}$ & $2.898(1 .|7|-7 . \mid 70)^{*}$ \\
\hline $30-39$ years & 24 & 110 & $1.072(0.57 \mathrm{I}-2.01 \mathrm{I})$ & $0.508(0.204-1.262)$ \\
\hline \multicolumn{5}{|l|}{ Adherence } \\
\hline Good ( $(\geq 95 \%)$ & 41 & 240 & I & I \\
\hline Poor (<95\%) & 46 & 36 & $7.480(4.326-12.934)^{*}$ & $6.060(2.837-12.944)^{* * *}$ \\
\hline \multicolumn{5}{|l|}{ Disclosure status } \\
\hline Current parent/close relatives & 43 & 107 & I & I \\
\hline Friends or colleague & 12 & 153 & $0.195(0.098-0.388)$ & $0.232(0.095-0.566)^{* *}$ \\
\hline Not disclosed & 32 & 16 & $4.977(2.480-9.989)^{*}$ & $4.178(1.431-12.198)^{* *}$ \\
\hline \multicolumn{5}{|l|}{ Condom use } \\
\hline Yes & 17 & 107 & 1 & I \\
\hline No & 70 & 169 & $2.607(1.456-4.669)^{*}$ & $1.469(0.565-3.82 \mathrm{I})$ \\
\hline \multicolumn{5}{|l|}{ Default treatment } \\
\hline Yes & 19 & 15 & $4.862(2.348-10.065)^{*}$ & $\mathrm{I} .249(0.32 \mathrm{I}-4.860)$ \\
\hline No & 68 & 261 & 1 & I \\
\hline \multicolumn{5}{|l|}{ Opportunistic infection } \\
\hline Yes & 42 & 33 & $6.873(3.942-11.983)^{*}$ & $4.110(1.827-9.246)^{* *}$ \\
\hline No & 45 & 243 & 1 & I \\
\hline \multicolumn{5}{|l|}{ CD4 count } \\
\hline$>350$ cells $/ \mathrm{mm}^{3}$ & 34 & 223 & 1 & I \\
\hline $100-350$ cells $/ \mathrm{mm}^{3}$ & 27 & 31 & $5.713(3.044-10.722)^{*}$ & $5.442(2.191-13.513)^{* * *}$ \\
\hline$<100$ cells $/ \mathrm{mm}^{3}$ & 26 & 22 & $7.751(3.956-15.189)^{*}$ & $3.497(1.233,9.923)^{*}$ \\
\hline \multicolumn{5}{|l|}{$B M 1$ in $\mathrm{kg} / \mathrm{m} 2$} \\
\hline$\geq 18.5 \mathrm{~kg} / \mathrm{m}^{2}$ & 46 & 236 & 1 & I \\
\hline $16-18.49 \mathrm{~kg} / \mathrm{m}^{2}$ & 17 & 28 & $3.115(1.577-6.151)^{*}$ & $2.00 I(0.77 I-5.194)$ \\
\hline$<16 \mathrm{~kg} / \mathrm{m}^{2}$ & 24 & 12 & $10.261(4.791-21.975)^{*}$ & $7.223(2.218-23.520)^{* *}$ \\
\hline \multicolumn{5}{|c|}{ Duration on second line ART in months } \\
\hline$\geq 2$ years & 24 & 111 & 1 & 1 \\
\hline$<2$ years & 63 & 165 & $1.766(1.04 \mathrm{I}-2.995)^{*}$ & I.873 (0.805-4.355) \\
\hline
\end{tabular}

Notes: $*$ Pvalue $<0.05, * * P$-value $<0.01, * * * P$-value $<0.001$.

who disclosed only to friends or work colleagues were 3.4-times more likely to experience virologic failure compared to those who disclosed to a partner or close relative. ${ }^{20}$ Therefore, not disclosing their HIV status may be due to HIV-related stigma or discrimination, which could affect patients' abilities to access social support (sexual partnerships and supportive care) as well as economic well-being (employability and food security).

The other findings were patients who had opportunistic infection in their medical record were 4-times more likely to develop virologic failure as compared to those patients who had opportunistic infection. The results were consistent with a study conducted in South India where the odds of developing treatment failure among patients who had opportunistic infection both prior to and after initiation of ART were strongly associated with virologic failure. Also those patients experience diarrhea found to be significantly associated with treatment failure. ${ }^{22}$ A study done in south Africa shows a patient who had no history of TB had lower risk of developing virologic failure. ${ }^{23}$ 
Opportunistic infections are the predominant causes of morbidity and mortality among HIV-infected patients. This may result in more rapid progression of HIV disease. On the other hand, rapid progression of HIV increases the susceptibility to be infected by different opportunistic infections, increased viral replication, reduced immunity, and finally clinically deterioration of the patient.

The study also identified that those patients who had a CD4 count $<350$ cells $/ \mathrm{mm}^{3}$ were more likely to develop virologic failure as compared to those patients who had a CD4 count $\geq 350$ cells $/ \mathrm{mm}^{3}$. This is in line with the studies conducted in Henan province of China; Cambodia, Rwanda, and Northwestern Tanzania, which show virologic failure was more common in patients CD4 cell counts less than $350 \mathrm{cells} / \mathrm{mm}^{3}$ at switch to second line ART were associated with virologic treatment as compared to $\geq 350$ cells $/ \mathrm{mm}^{3.12,20,24,25}$ This may be because a patient's immune status becomes compromised, and the rate of viral replication increases compared to their immune-competent counterparts. Furthermore, clients with compromised immunity are more vulnerable to different opportunistic infections that sustain the vicious cycle of immunity and viral replication increased.

In addition, the study identified that those patients who had low $\mathrm{BMI}<16 \mathrm{~kg} / \mathrm{m}^{2}$ were more likely to develop virologic failure as compared to those patients who had normal BMI $\left(\geq 18.5 \mathrm{~kg} / \mathrm{m}^{2}\right)$. This result is in line with a study conducted in South Africa indicating having a low BMI $<16 \mathrm{~kg} / \mathrm{m}^{2}$ was associated with virologic failure as compared to normal BMI $\left(16-18 \mathrm{~kg} / \mathrm{m}^{2}\right)$ patients. ${ }^{19}$ In addition, a study done in northwest Ethiopia with low BMI $<16 \mathrm{~kg} / \mathrm{m}^{2}$ has been linked with HIV associated morbidity and mortality. ${ }^{26}$ This is due to low BMI patients compromising their immunity result in exposed for opportunistic and other comorbid disease so their bodies immune system could not control the viral multiplication.

The study identified that patients of a younger age (15-29 years) were more likely to develop virologic failure as compared to those patients who were $\geq 40$ years of age. Similar findings were reported from Rwanda, Malawi, and Zimbabwe, where the odds of develop virologic failure on second line ART adult patients in the age category of 15-29years were associated with virologic failure. ${ }^{27-29}$ In northern Tanzania the odds of virologic failure among younger age less than 30 years were more likely associated with second line ART virologic failure. ${ }^{15}$ In general, younger age is usually associated with virologic failure due to a number of unique behavioral and psychosocial factors like anxiety, stigma, and lack of disclosure, low social economic status, and poor adherence to ART medication. This finding highlights the value of focusing on the special needs of the younger age group HIV patients on second line ART to achieve the third 90 target.

\section{Limitations of the Study}

Recall bias for some variables may have occured.

\section{Conclusion}

The study identified that determinants of virologic failure on second line ART who had poor adherence to ART medication, had not disclosed their HIV status, opportunistic infection, Low CD4 counts less than $350 \mathrm{cell} / \mathrm{mm}^{3}$ at switchto second line ART, low BMI $\left(<16 \mathrm{~kg} / \mathrm{m}^{2}\right)$, and young age group (15-29 years old) patients were significantly associated with second line ART virologic failure.

\section{Recommendations}

\section{For Patients}

Do not miss their medication for any reasons, they get social supports and other benefits by disclosing their HIV status and get early treatment for any opportunistic infection without delay.

\section{For Healthcare Providers}

The healthcare providers should aim for early identification of patients during follow-up visit who had poor adherence, opportunistic infection, low CD4 count, malnourished patients, younger age group, and nondisclosed patients who will need closer clinical follow-up.

\section{For Hospital Managers}

Avail the third line ART medication for those who failed for second line ART if possible or link to other facilities with referral and also avail therapeutic food for malnutrition patients.

\section{For Researchers}

Researchers do further investigation by using other study designs like cohort and qualitative to explore cultural taboos and more determinants.

\section{Abbreviations}

AIDS, acquired immune deficiency syndrome, ART, antiretroviral therapy; BMI, body mass index; CD4, cluster of differentiation four; $\mathrm{CEO}$, chief finance office; CI, 
confidence interval; EAC, enhancing adherence counseling; FMOH, Federal Ministry of Health; HIV, human immunodeficiency virus; MDT, multi-disciplinary team; NNRTI, non-nucleotide reverse transcriptase inhibitors; OI, opportunistic infection; OR, odds ratio; PLHIV, people living with HIV; RLS, resource limited setting; TB, tuberculosis; UNAIDS, United Nation Joint HIV/Aids Program; VF, virologic failure; VL, viral load; WHO, World Health Organization.

\section{Data Sharing Statement}

The datasets generated and/or analyzed during the current study are not publicly available due to lack of databases in our institution, but are available from the corresponding author on reasonable request.

\section{Ethics Approval and Consent to Participants}

Ethical approval was obtained from the ethical review board of Wollo University, College of Medicine and Health Sciences, School of public health. Permission was obtained from each hospitals CEO, Medical Director, and other concerned bodies working at the ART clinic. Each study participant had the objective of the study clearly explained to them in order to obtain their verbal consent, including their full right to withdraw or refuse to participate. Privacy and confidentiality of information taken from each client and their medical chart were kept properly and names were not recorded. The informed verbal consent process was approved by the ethical review board of Wollo University, and all participants or the parents/legal guardians of patients under the age of 18 provided informed verbal consent to take part in this study. The study also complies with the full filed ethical principles of Helsinki Declaration in research.

\section{Acknowledgments}

First, we would like to thank Wollo University for giving the opportunity and support to do this research. We would also like to express our heartfelt thanks to our friends who support us and each study hospitals health workers who work at ART clinic for their cooperativeness, for data collectors, and study participants greatly.

\section{Author Contributions}

All authors contributed to the conceptualization, data analysis, drafting or revising of the article, have agreed on the journal to which the article will be submitted, gave final approval of the version to be published, and agree to be accountable for all aspects of the work.

\section{Funding}

Wollo University funded the research. The funders had no role in study design, data collection and analysis, decision to publish, or preparation of the manuscript.

\section{Disclosure}

The authors report no conflicts of interest for this work.

\section{References}

1. Ethiopian national consolidated hiv prevention, comprehensive guidelines for care and treatment August, 2018. 2018.

2. Assefa Y. School of allied health sciences treatment outcomes of HIV-infected patients on second line ART in selected health facilities of Addis Ababa. ResearchGate. 2017.

3. Gupta Sanjeeva RS, KUMER Alok S. National Technical Guidelines on Anti Retroviral Treatment. Vol. 36. NACO; 2018:1-282.

4. Agnes E, Laker O, Nabaggala MS, et al. An observational study in an urban Ugandan clinic comparing virological outcomes of patients switched from first- line antiretroviral regimens to second-line regimens containing ritonavir-boosted atazanavir or ritonavir-boosted lopinavir. BMC Infect Dis. 2019;19(280):1-7.

5. Shroufi A, Van Cutsem G, Cambiano V, et al. Simplifying switch to second-line antiretroviral therapy in sub Saharan Africa: predicted effect of using a single viral load to define efavirenz-based first-line failure. OPEN. 2019;33(10):1635.

6. Tsegaye AT, Wubshet M, Awoke T, Alene KA. Predictors of treatment failure on second-line antiretroviral therapy among adults in northwest Ethiopia: a multicentre retrospective follow-up study. $B M J$ Open. 2016;1-8.

7. Access O. Incidence and determinants of mortality among adult HIV infected patients on second-line antiretroviral treatment in Amhara region, Ethiopia: a retrospective follow up study. PanAfricanMedicalJournal. 2019;8688:1-12.

8. Nguyen H, Kuritzkes D, Marconi VC, Nachega JB. Second-line antiretroviral therapy: long-term outcomes in South Africa. $N I H$ Public Access. 2013;61(October):158-163.

9. Notes R, Alene M, Awoke T, et al. Second - line antiretroviral therapy regimen change among adults living with HIV in Amhara region: a multi - centered retrospective follow - up study. BMC Res Notes. 2019;1-6.

10. Alene M, Awoke T, Yenit MK, Tsegaye AT. Incidence and predictors of second-line antiretroviral treatment failure among adults living with HIV in Amhara region: a multi-centered retrospective follow-up study. BMC Infect Dis. 2019;1-9.

11. Thu N, Kyaw T, Kumar AMV, et al. Long-term outcomes of second-line antiretroviral treatment in an adult and adolescent cohort in Myanmar. Glob Health Action. 2017;10(1):1-11.

12. Gunda DW, Kilonzo SB, Mtaki T, Bernard DM, Kalluvya SE, Shao ER. Magnitude and correlates of virological failure among adult HIV patients receiving PI based second line ART regimens in north western Tanzania; a case control study. BMC Infect Dis. 2019;19(235):1-7. doi:10.1186/s12879-019-3852-3

13. Evans D, Hirasen K, Berhanu R, et al. Predictors of switch to and early outcomes on third - line antiretroviral therapy at a large public sector clinic in Johannesburg, South Africa. AIDS Res Ther. 2018;15 (10): $1-12$.

14. The need for routine viral load testing. 2016. 
15. Id FK, Esber A, Musingye E, et al. HIV virologic failure and its predictors among HIV-infected adults on antiretroviral therapy in the African Cohort Study. PLoS One. 2019;396:1-16.

16. Action GH. Retention in care among HIV-positive patients initiating second-line antiretroviral therapy: a retrospective study from an Ethiopian public hospital clinic. Glob Health Action. 2016;9716:1-9.

17. Sciences H, Sciences H Determinants of first line antiretroviral immunologic treatment failure among adult HIV patients at Dessie Referral Hospital, South Wollo zone, Ethiopia, June, 2015. 2015.

18. Dessie referal and Woldia zonal hospitals monthly report, February,2020. 2020.

19. Therapy S, Fox MP. Predicting the need for third-line antiretroviral therapy by identifying patients at high risk for failing second-line antiretroviral therapy in South Africa. Clin Epidemiol Res. 2017;31 (5):205-212

20. Ségéral O, Nerrienet E, Neth $\mathrm{S}$, et al. Positive virological outcomes of HIV-infected patients on protease inhibitor-based second-line regimen in Cambodia. Front Public Health. 2018;6(march):1-9.

21. Brian P. Factors Associated with Viral Suppression Among Adolescents on Antiretroviral Therapy in Homabay County, Kenya Supervisor. Prof Brain van wyk; 2019.
22. Sadashiv MS, Rupali P, Manesh A, et al. Risk factors of clinical and immunological failure in South Indian cohort on generic antiretroviral therapy. Assoc Physicians India. 2017;65(December):3-8.

23. Narainsamy D, Mahomed S, Africa S, Africa S. Delays in switching patients onto second-line antiretroviral treatment at a public hospital in Thekwini, KwaZulu-Natal. South Afr J HIV Med. 2017;18 (march):1-5.

24. Meng X, Liu L, Li Q, et al. HIV drug resistance and related factors in patients receiving second-line combination antiretroviral therapy in rural China. Orig Artic. 2017;10(1):1127-1132.

25. Nsanzimana S, Semakula M, Ndahindwa V, et al. Retention in care and virological failure among adult HIV + patients on second-line ART in Rwanda: a national representative study. BMC Infect Dis. 2019;19:1-9. doi:10.1186/s12879-019-3934-2

26. Ongubo DM, Lim R, Tweya H, et al. A cross-sectional study to evaluate second line virological failure and elevated bilirubin as a surrogate for adherence to atazanavir/ritonavir in two urban HIV clinics in Lilongwe, Malawi. BMC Infect Dis. 2017;17(461):1-10. doi:10.1186/s12879-017-2528-0

\section{Publish your work in this journal}

HIV/AIDS - Research and Palliative Care is an international, peerreviewed open-access journal focusing on advances in research in HIV, its clinical progression and management options including antiviral treatment, palliative care and public healthcare policies to control viral spread. The manuscript management system is completely online and includes a very quick and fair peer-review system, which is all easy to use. Visit http://www.dovepress.com/testimonials.php to read real quotes from published authors. 